\title{
Rppl, an essential protein subunit of nuclear RNase P required for processing of precursor tRNA and 35S precursor rRNA in Saccharomyces cerevisiae
}

\author{
Viktor Stolc ${ }^{1}$ and Sidney Altman ${ }^{2,3}$ \\ ${ }^{1}$ Department of Cell Biology, Yale University School of Medicine, N ew Haven, Connecticut 06510 USA; ${ }^{2}$ Department of \\ Biology, Yale University, N ew Haven, Connecticut 06520 USA
}

\begin{abstract}
The gene for an essential protein subunit of nuclear RNase P from Saccharomyces cerevisiae has been cloned. The gene for this protein, RPP1, was identified by virtue of its homology with a human scleroderma autoimmune antigen, Rpp30, which copurifies with human RNase P. Epitopetagged Rppl can be found in association with both RNase P RNA and a related endoribonuclease, RNase MRP RNA, in immunoprecipitates from crude extracts of cells. Depletion of Rppl in vivo leads to the accumulation of precursor tRNAs with unprocessed 5' and 3' termini and reveals rRNA processing defects that have not been described previously for proteins associated with RNase P or RNase MRP. Immunoprecipitated complexes cleave both yeast precursor tRNAs and precursor rRNAs.
\end{abstract}

[Key Words: Rpp1; essential protein subunit; nuclear RN ase P; S. cerevisiae; precursor tRNA; precursor rRN A] Received June 5, 1997; revised version accepted July 25, 1997.

Ribonucl ease $P$ ( $R N$ ase $P$ ) is a ubiquitous endoribonuclease that consists of protein and RN A subunits. It cleaves 5 '-terminal leader sequences of precursor tRNAs (Darr et al. 1992; Altman et al. 1993). Escherichia coli RN ase P is also known to process precursors of other small, metabiologically stable RNAs in vivo, such as 4.5S RNA (Bothwell et al. 1976), 10Sa RNA (Komine et al. 1994), the polycistronic mRN A from the histidine operon (Alifano et al. 1994), and some small RN As encoded by bacteriophage (Bothwell et al. 1974; Hartmann et al. 1995). In eubacteria, the RN A component al one of RN ase $P$ is catalytic in vitro (Guerrier-Takada et al. 1983). The eubacterial protein subunit is a basic protein of $\sim 14 \mathrm{kD}$ and serves as an essential cofactor in vivo by enhancing the catalytic efficiency and substrate range of the holoenzyme (Liu and Altman 1994; Gopalan et al. 1997). In contrast, the RNA components of archaeal and eukaryotic RN ase $P$ are not catalytically active in vitro in the absence of their respective protein subunits, despite their structural homology to the eubacterial RN As (Altman et al. 1995; Haas et al. 1996).

Although the RNA subunit of nuclear RN ase $P$ has been characterized from a variety of eukaryotic organisms (Altman et al. 1993; Tranguch and Engelke 1993; Chamberlain et al . 1996a; Eder et al. 1996), information regarding the protein subunits of eukaryotic RN ase $P$ is

${ }^{3}$ Corresponding author.

E-MAIL sidney.altman@qm.yaleedu; FAX (203) 432-5713. limited. RN Ase $P$ isolated from human cells copurifies with an RN A ( $\mathrm{H} 1 ; 340)$, and at least six proteins-Rpp14, Rpp20, Rpp25, Rpp30, Rpp38, and Rpp40 (Eder et al. 1997). Genetic approaches in Saccharomyces cerevisiae have identified three essential proteins, Pop1, Pop3, and Pop4, which associate with RN ase P RNA (RPR1); these proteins al so associate with the RN A (N ME1) of a related endoribonuclease, RN ase mitochondrial RNA processing (MRP) (Schmitt and Clayton 1992; Lygerou et al. 1994; Dichtl and Tollervey 1997; Chu et al . 1997). Analysis of temperature-sensitive alleles of these proteins or depletion of these proteins in yeast cells has shown that all three have a role in tRN A processing as well as rRN A processing. It has been suggested that tRNA and rRN A processing are coordinated (Pace and Burgin 1990; Clayton 1994; M orrissey and Tollervey 1995; Lee et al. 1996).

In eukaryotes, coordination of tRN A and rRNA processing may be mediated by the activity of two related enzymes, RN ase P and RN ase M RP (M orrissey and Tollervey 1995; Chamberlain et al. 1996b). RN ase $P$ is essential for biosynthesis of tRN As (Lee et al. 1991) and also appears to have a role in rRN A processing in yeast (Chamberlain et al. 1996b). RN ase MRP is related to RNase $P$ by structural similarities found in its RNA component (Forster and Altman 1990; Schmitt et al. 1993). It has been suggested that $R N$ ase $P$ is an ancestor of RN ase MRP (Morrissey and Tollervey 1995). RN ase MRP was described originally as an endonuclease that cleaves RN A primers for mitochondrial DNA replication 
(Chang and Clayton 1987; Stohl and Clayton 1992). Recently, its role in nuclear processing of precursor rRN A (prRN A) has been established (Lygerou et al. 1996a). RN ase MRP does not cleave precursor tRN As (ptRNAs) in vitro, and depletion of NME1 RNA does not affect tRN A processing in vivo (Schmitt and Clayton 1993; Lygerou et al. 1996a). However, when proteins associated with RN ase M RP are depl eted or inactivated by a mutation in yeast, cleavage of ptRN As is blocked (Lygerou et al. 1994; Chu et al. 1997; Dichtl and Tollervey 1997).

To learn more about the functions of nuclear RN ase $P$ in vivo, we report here the cloning and functional characterization of an essential protein (Rpp1, 32.2 kD) component of S. cerevisiae RN ase P. Rpp1 is homologous to the human scleroderma autoimmune antigen, Rpp30, which was identified recently as a protein that copurifies with human RN ase $P$ and that is recognized by sera from patients with autoimmune disease that is referred to as Th/To antisera (Eder et al . 1997). To identify novel functions of RN ase $P$ in yeast, a strain of $\mathrm{S}$. cerevisiae that conditionally expresses Rppl protein was constructed. Using this strain and a strain that contains an epitopetagged RPP1 gene, we demonstrate a role for Rppl in processing tRN A and ribosomal RN A precursors. Depletion of Rppl protein revealed global defects in rRNA processing. Depletion or inactivation of proteins associated with RN ase P or RN ase M RP affect only a subset of the same rRN A processing events (Lygerou et al. 1994; Chu et al . 1997; Dichtl and Tollervey 1997). Based on the observed defects in rRNA processing, we suggest a possible functional interaction of RNase $P$ with RN ase $M R P$, and other small nucleol ar ribonucl eoprotein (RNP) complexes (snoRNP; for review, see Filipowicz and Kiss 1993; Fournier and M axwell 1993; M axwell and Fournier 1995), which is required for processing of prRNA.

\section{Results}

An essential yeast gene encodes a homolog of the human scleroderma autoimmune antigen, Rpp30

We used a combination of bi ochemical and genetic studies in human and S. cerevisiae cells to characterize a protein subunit of eukaryotic RN ase P. We employed a computational sequence search of yeast genes that have amino acid sequence similarity to biochemically identified human RN ase P protein subunits (Eder et al . 1997). To determine which of the proteins associated with human RNase $\mathrm{P}$ might be essential components required for catalytic function (Eder et al. 1997), we searched for homologs of Rpp14, Rpp20, Rpp25, Rpp30, Rpp38, and Rpp40 in the genome of S. cerevisiae (Goffeau et al. 1996) by performing a BLAST search (blastp and tblastn algorithms; Altschul et al. 1990) of the S. cerevisiae genome database (Cherry et al. 1996). The human scleroderma autoi mmune antigen, Rpp30, has the highest amino acid sequence similarity to a predicted sequence. A previously uncharacterized open reading frame (ORF), YHR062C, on the right arm of chromosome VIII has the potential to encode a protein of $32.2 \mathrm{kD}$ and shares $23 \%$ amino acid sequence identity with human Rpp 30 (Fig. $1 A$ ). This yeast gene is now named RPP1 for $\underline{R}$ ase $\underline{P}$ Protein 1.

To address whether the putative protein encoded by RPP1 is an essential gene, we disrupted this gene by replacing it with the LEU 2 gene (see M aterial s and M ethods). The heterozygous RPP1/rpp1::LEU 2 strain (VS161) was sporulated and subsequent tetrad analysis showed a 2:2 segregation for cell viability (Fig. 1B). All viable spores were Leu-, indicating that they had the wild-type RPP1 allele. Therefore, RPP1 is an essential gene in S. cerevisiae.

\section{Construction of an epitope-tagged allele of RPP1}

Epitope-tagged proteins are useful in the study of subunit function and interactions in large holoenzyme complexes. To determine whether or not Rppl associates with RPR 1 RN A and RN ase P activity, an epitope-tagged RPP1 strain of S. cerevisiae (VS162) was constructed (Table 1). A DNA fragment that encodes three copies of a c-myc epitope ( $3 \times$ myc; T erBush and N ovick 1996) was fused in-frame $3^{\prime}$ to the initiator ATG codon of RPP1 in a low-copy-number plasmid (pRS316), pRS316::3 ×mycRPP1. The resulting strain grew at identical rates to the wild-type cells suggesting that the $3 \times$ myc-RPP1 allele is fully functional (Fig. 2A, lanes 2,4). Immunoblots of protein extracts from $3 \times$ myc-RPP1 cells using an antimyc antibody (9E10) detected a polypeptide of $36 \mathrm{kD}-$ the size is consistent with that predicted for the $3 \times$ myc-Rppl fusion protein (Fig. 2B, lanes 2,4). Wildtype haploids (VS162A and VS162C) lacking the c-myc tag do not contain the 36-kD protein. These results show that the myc epitope-tagged Rppl protein migrates as a 36-kD polypeptide and is fully functional .

RNase P and RNase MRP RNAs coprecipitate with the $3 \times$ myc-Rppl fusion protein

Whether or not Rppl is associated with RN ase P RNA was determined by immunoprecipitation experiments (Fig. 3). Extracts from $3 \times$ myc-RPP1 and RPP1 strains were incubated with anti-myc monoclonal antibody (9E10) and RN A was extracted from the immunoprecipitates (see $M$ aterials and M ethods). The RN A was 3' endlabeled with $\left.{ }^{32} \mathrm{P}\right] \mathrm{pC} \mathrm{p}$ and analyzed by denaturing gel electrophoresis (Fig. 3A,B). Immunoprecipitatd RN A was also analyzed by $\mathrm{N}$ orthern hybridization to confirm the identity of the labeled RNAs (Fig. 3C,D). M ature RN ase $P$ RNA is the major RNA species found in the $3 \times$ mycRppl precipitate from $3 \times$ myc-RPP1 cells but not from the control cell Iysates. Two putative precursors of RN ase P RN A (Lee et al. 1991) and RN ase MRP RNA are also found in immunoprecipitates from $3 \times$ myc-RPP 1 but not in control immunoprecipitates. A pproximately equal levels of RN ase $P$ and RN ase M RP RN As (RPR 1 and N M E1, respectively) were found in end-labeled RN A derived from immunoprecipitates that were washed with buffer that contained $150 \mathrm{~mm} \mathrm{KCl}$ (Fig. 3A). However, RN ase P RNA is the major RNA species detected 
Figure 1. RPP1, an essential yeast gene encodes a 32.2-kD protein ortholog of the human scleroderma autoimmune antigen, Rpp30. (A) Predicted amino acid sequence of S. cerevisiae Rpp1. The protein is encoded by ORF YHR062c on chromosome VIII and its alignment with the human scleroderma autoimune antigen Rpp30 is shown. The amino acid sequences are numbered from the first methionine residue of each protein. Identical amino acids are shaded and similar amino acids are boxed. (B) The heterozygous diploid strain VS161, RPP1/rpp1::LEU 2, was sporulated and dissections were performed on 20 tetrads. The four spores (A-D) derived from each of five tetrads are shown in vertical rows.

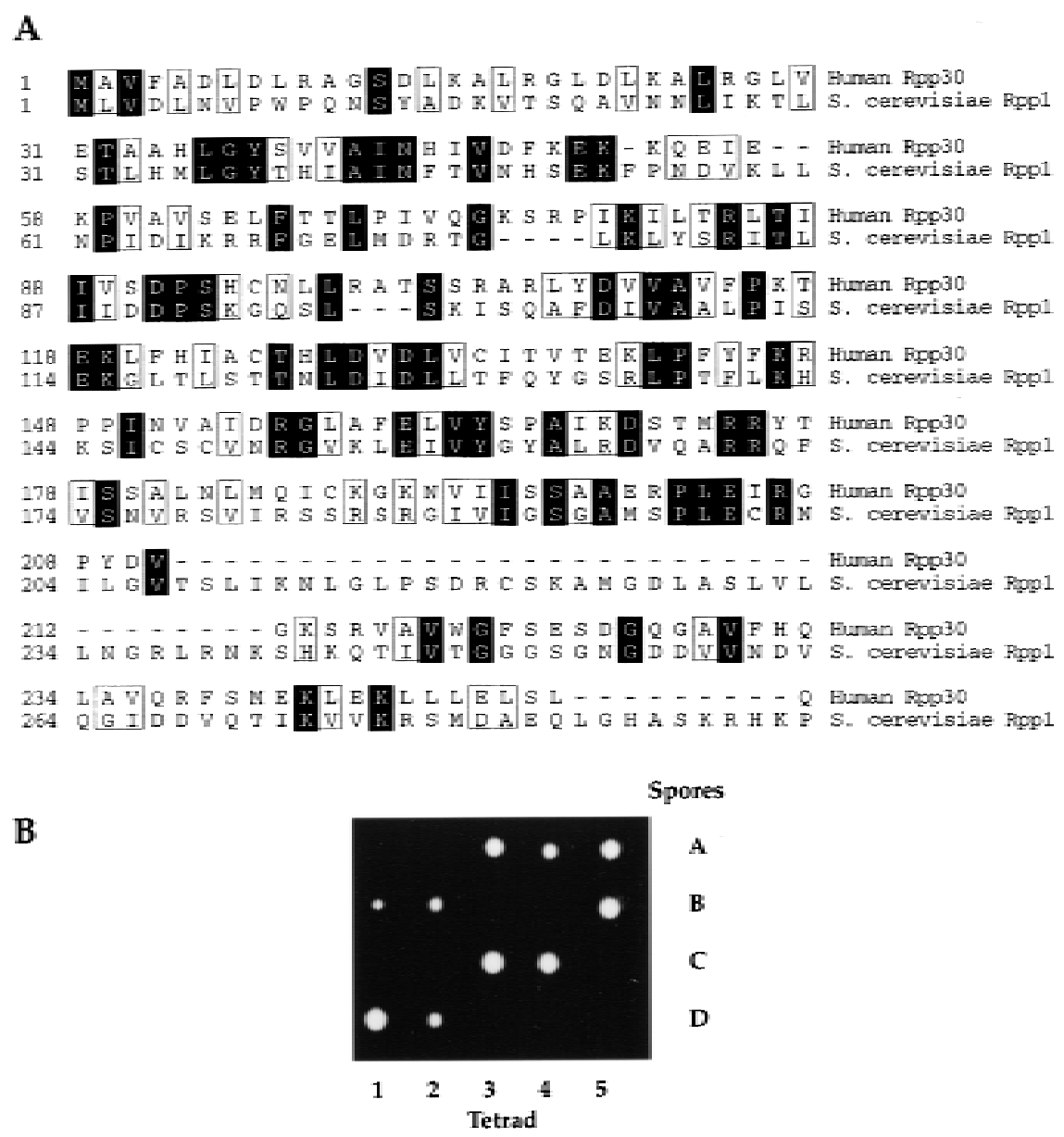

by 3 ' end-labeling of RNA in $3 \times$ myc-Rppl immunoprecipitates that were washed with buffer that contained $600 \mathrm{~mm} \mathrm{KCl}$ (Fig. 3B). Therefore, it is possible to achieve a significant separation of the two enzymes, both physically and functionally (Lygerou et al. 1996a; and see below).
The association of Rppl with RN ase P activity was also demonstrated by immunoprecipitation. Immunoprecipiated (and resuspended) $3 \times$ myc-Rppl pellets accurately cleaved radiolabeled ptRNA ${ }^{\text {Ser }}$ (Fig. 4) and ptRN A ${ }^{\text {Tyr }}$ (data not shown) in vitro. We conclude that Rppl protein is a component of, or is tightly associated

Table 1. Strains of S. cerevisiae used in this study

\begin{tabular}{ll}
\hline Strain & Genotype \\
\hline JN161 & MATa/MAT $\alpha$ ade2-1/ade2-1 leu2-3,112/leu2-3,112 ura3-1/ura3-1 his4-260/his4-260 thr1-4/thr1-4 lys2 $\triangle$ Nhel/lys2 $\triangle$ Nhel \\
VS161 & MATa/MAT $\alpha$ ade2-1/ade2-1 leu2-3,112/leu2-3,112 ura3-1/ura3-1 his4-260/his4-260 thr1-4/thr1-4 lys2 $\triangle$ Nhel/lys2 $\triangle$ Nhel \\
& RPP1/rpp1::LEU 2/RPP1 \\
VS162 & MATa/MAT $\alpha$ ade2-1/ade2-1 leu2-3,112/leu2-3,112 ura3-1/ura3-1 his4-260/his4-260 thr1-4/thr1-4 lys2 $\triangle$ Nhel/lys2 $\triangle$ Nhel \\
& RPP1/rpp1::LEU 2/RPP1 +pRS316-3xmyc::RPP1 \\
VS162A & MATa ade2-1 leu2-3,112 ura3-1 his4-260 thr1-4 lys2 $\triangle$ Nhel RPP1 +pRS316-3xmyc::RPP1 \\
VS162B & MATa ade2-1 leu2-3,112 ura3-1 his4-260 thr1-4 lys2 $\triangle$ Nhel rpp1::LEU 2 + pRS316-3xmyc::RPP1 \\
VS162C & MAT $\alpha$ ade2-1 leu2-3,112 ura3-1 his4-260 thr1-4 lys2 $\triangle$ Nhel RPP1 + pRS316-3xmyc::RPP1 \\
VS162D & MAT $\alpha$ ade2-1 leu2-3,112 ura3-1 his4-260 thr1-4 lys2 $\triangle$ Nhel rpp1::LEU 2 + pRS316-3xmyc::RPP1 \\
VS162A' & MATa ade2-1 leu2-3,112 ura3-1 his4-260 thr1-4 lys2 $\triangle$ Nhel RPP1 \\
VS162C' & MAT $\alpha$ ade2-1 leu2-3,112 ura3-1 his4-260 thr1-4 lys2 $\triangle$ Nhel RPP1 \\
NY1060 & MATa/MAT $\alpha$ GAL1/GAL1 leu2-3,112/leu2-3,112 ura3-1/ura3-1 \\
VS163 & MATa/MAT $\alpha$ GAL1/GAL1 leu2-3,112/leu2-3,112 ura3-1/ura3-1 RPP1/rpp1:::LEU 2 \\
VS164 & MAT $\alpha$ GAL1 leu2-3,112 ura3-1 + pYCpGAL::rpp1 (URA3) \\
VS165 & MAT $\alpha$ GAL1 leu2-3,112 ura3-1 + pYCpGAL (URA3) \\
\hline
\end{tabular}


with, catalytically active RN ase $\mathrm{P}$ holoenzyme. Indirect supporting evidence for this conclusion comes from experiments in which the human homolog of Rpp1, Rpp30, was shown not to be separable from the active hol oenzyme after extensive biochemical purification (Eder et al . 1997).

\section{Construction of a conditional lethal allele of RPP1}

RPP1 was placed under the control of the GAL10 promoter, which allows expression of the gene in culture medium that contains galactose but suppresses expression in culture medium that contains glucose. The resulting strain, rpp1::LEU2-pGAL::rpp1 (VS164), was compared in phenotype to the control strain RPP1pGAL (VS165). In liquid culture that contained galactose, there was no difference in growth rate between the GAL::rpp1 strain and the wild-type RPP1 strain. After the cultures were transferred to medium that contained glucose, cell growth continued initially with a doubling time of $2 \mathrm{hr}$. After $12-16 \mathrm{hr}$, the growth rate of the
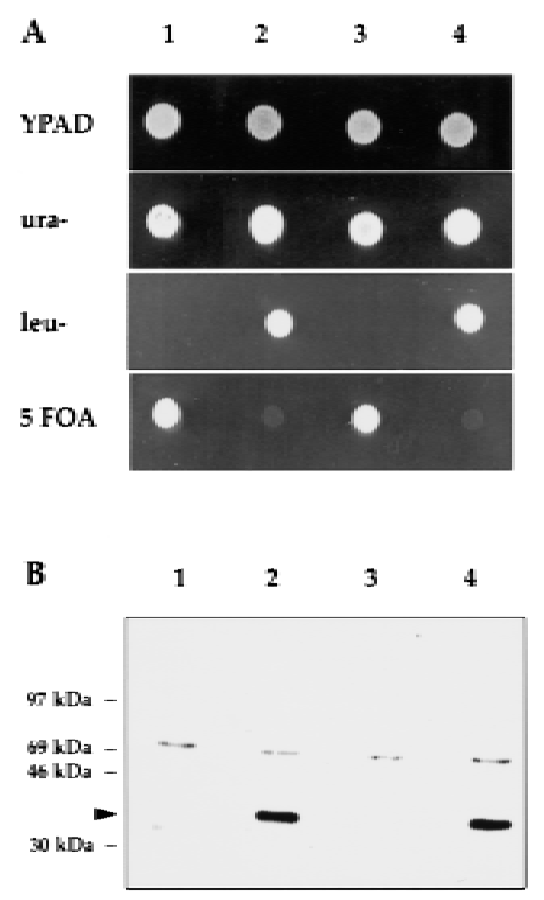

Figure 2. $3 \times$ myc-Rppl is functional and recognized by $9 \mathrm{E} 10$ antibody. (A) The four spores (VS162 A-D; lanes 1-4, respectively) derived from the diploid strain VS162, were dissected on rich medium plates (YPAD), and then replica-plated onto plates that contained synthetic complete medium that lacked either leucine (leu) or uracil (ura), or that contained 5-FOA. (B) Immunoblot of protein extracts prepared from the four spores VS162A', VS162B, VS162C', and VS162D, derived from the diploid strain VS162. All four spores are isogenic except the VS162A' and VS162C' spores do not have the pRS316-3 $\times$ mycRpp1 plasmid. (Lanes 1-4) VS162A', VS162B, VS162C', and VS162D, respectively. The arrowhead points to the $36-k D$ $3 \times$ myc-Rppl fusion protein. The upper band is a nonspecifically reacting protein.

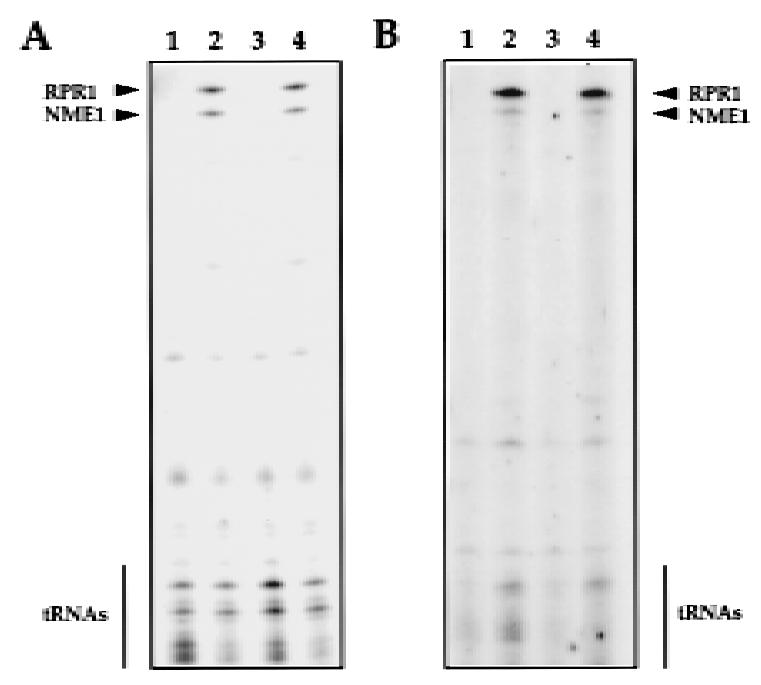

C

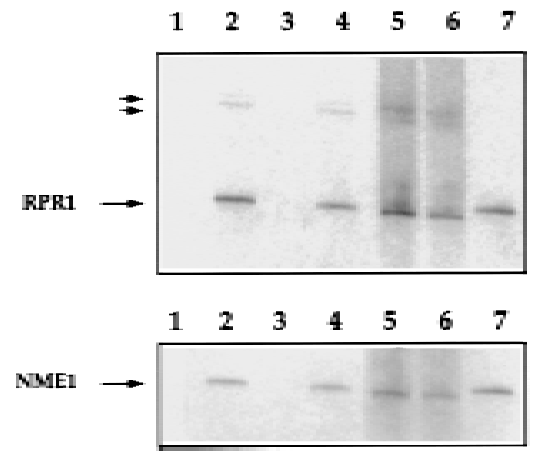

Figure 3. The RNA subunits of $R N$ ase $P(R P R 1)$ and $R N$ ase MRP (N ME1) coprecipitate with $3 \times$ myc-Rppl. (A) Immunoprecipitated RNAs extracted from the 9E10 Ab-IgG-agarose beads that were incubated with protein extracts from the four spores (VS162A' ', VS162B, VS162C' , and VS162D; Ianes 1-4, respectively). RNA was extracted from the immunoprecipitated beads that were washed with $150 \mathrm{~mm} \mathrm{KCl}$ (see Materials and Methods). The RN A was $3^{\prime}$ end-labeled with [5'-32 $\left.\mathrm{P}\right] \mathrm{pCp}$, and fractionated on a $8 \%$ polyacrylamide/ $7 \mathrm{~m}$ urea gel. (B) Immunoprecipitated RNAs derived from the same immunoprecipitated beads as in A (lanes 1-4, respectively) except that the immunopreci pitated beads were washed with $600 \mathrm{~mm} \mathrm{KCl}$ prior to $3^{\prime}$ end-labeling of the RN A. (C) Immunoprecipitated RNAS derived from the same immunoprecipitated beads as in A were transferred to a positively charged nylon membrane (Boehringer $M$ annhei $m$ ) by electroblotting and hybridized with a uniformly labeled DN A probe complementary to the RPR 1 gene (see Materials and Methods). (Lanes 1-4) Immunoprecipitated RNA from spores VS162A', VS162B, VS162C', and VS162D, respectively; (lane 5) RNA from supernatant of the immunoprecipitated extract derived from spore VS162A' after centrifugation of beads; (lane 6) RNA from supernatant of the immunoprecipitated extract derived from spore VS162B after centrifugation of beads; (lane 7) RN ase P (RPR1) and RN ase MRP (N ME1) RN As (0.001 pmoles each) transcribed in vitro. Two small arrows point to larger species, which may be precursors to mature RN ase P RN A, RPR1 (Lee et al. 1991). The larger arrows indicate RN ase P (RPR1) and RN ase M RP (N ME1) RN As. (D) Same as in $C$, except the membrane was hybridized with a uniformly labeled DNA probe complementary to the NME1 gene (Schmitt and Clayton 1992). 


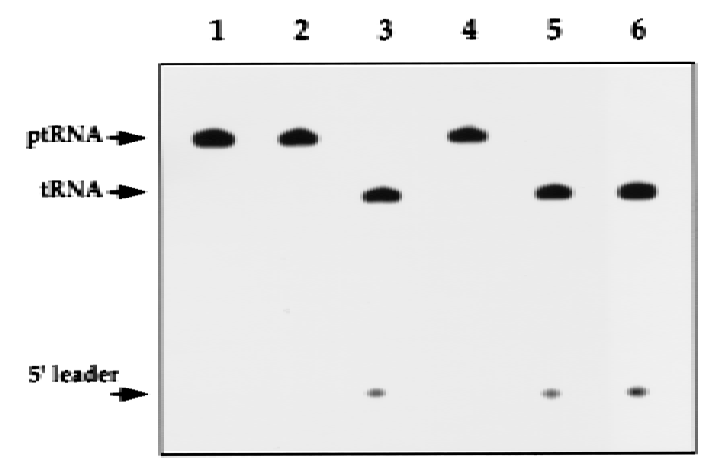

Figure 4. RN ase $P$ activity coprecipitates with $3 \times$ myc- $R p p 1$. IgG-agarose pellets, to which is bound immunoprecipitated RN ase P RN A, derived from spores VS162A', VS162B, VS162C', and VS162D (as in Fig. 3B), were incubated with a uniformly labeled precursor tRNA ${ }^{\text {Ser }}$ for $30 \mathrm{~min}$ at $37^{\circ} \mathrm{C}$, and then fractionated on a $8 \%$ polyacrylamide/ $7 \mathrm{M}$ urea gel (see $\mathrm{M}$ aterials and M ethods). (Lane 1) Precursor tRN A ${ }^{\text {Ser; }}$ (Ianes 2-5) immunoprecipitated RN ase $P$ from the four spores VS162A', VS162B, VS162C', and V6S162D, respectively; (lane 6) glycerol gradientpurified human RN ase P, fraction F29 (Eder et al. 1997). Arrows indicate ptRNA, accurately processed mature tRNA, and $5^{\prime}$ leader sequence.
GAL::rppl strain declined rapidly and there was little growth after $16 \mathrm{hr}$ (Fig. 5A).

\section{Rpp1 is required for processing of ptRNA}

To determine the effects of Rppl depletion on the biosynthesis of metabolically stable RNAs, total RNA was isolated from the GAL::rpp1 strain (VS164) and the RPP1 strain (VS165) at various times during growth in glucosecontaining medium. RNA samples from VS164 were compared with those from VS165 on a denaturing gel stained with ethidium bromide and by $\mathrm{N}$ orthern hybridization.

The effect of Rppl depletion on the accumulation of precursor tRN As is shown in Figure 5B. Several RN As began to accumulate at $7 \mathrm{hr}$ after transfer to glucosecontaining medium. At this time, the culture growth slowed. The abundance of these RN As increased with time and their sizes were appropriate for ptRN As. The abundance of mature tRNAs decreased accordingly. Analysis by Northern hybridization using probes complementary to tRNA ${ }^{\text {Leu3 }}$ (Fig. 5C), the intervening sequence (IVS) (data not shown) and 5 ' leader sequence
Figure 5. Rppl is required for processing of ptRNA and 5.8S rRNA in vivo. (A) Growth of the strain VS164 (ם), and the wild-type, isogenic strain VS165 ( $\square$ ), after transfer from gal actose-containing to glucose-containing medium at $\mathrm{T}=0$. Cell density was measured at the times indicated and the cultures were diluted with glucose-containing medium at each time point to prevent nutritional deprivation and to maintain exponetial growth. (B) RNA was extracted from VS164 following growth in glucose-containing medium at the indicated times, and was fractionated in an $8 \%$ polyacrylamide/ $7 \mathrm{M}$ urea gel, and stained with ethidium bromide. The positions of 5.8S (L) RNA, 5.8S (S) RNA, 5S RNA, ptRNA, and mature tRNA are indicated. (C) Total RN A extracted from VS164 and VS165 was transferred to a positively charged nyIon membrane (Boehringer $\mathrm{M}$ annheim) by electroblotting and hybridized with a $\gamma^{-32} \mathrm{P}$-labeled oligonucleotide complementary to mature tRNA ${ }^{\text {Leu }}$ (see Materials and M ethods). The position of the three processing intermediates of the ptRNA are indicated. PT is the primary transcript, which has extra sequences at both of its termini and contains an intron; IVS is the ptRNA that contains the intron but has been processed at both the $5^{\prime}$ and $3^{\prime}$ ends; $5^{\prime} 3^{\prime}$ is the spliced ptRNA that is unprocessed at both termini. (D) Steady-state levels of RN ase P RNA (RPR1) and RNase MRP RNA (NME1) in VS164 after transfer from galactosecontaining to glucose-containing medium. The upper band in the RPR 1 panel is the putative precursor RPRI RNA that has extra sequences at both termini (Lee et al. 1991). U6 snRN A levels were detected with oligo U6 (Table 2), as an internal control for RNA levels (Brow and Guthrie 1990).
A
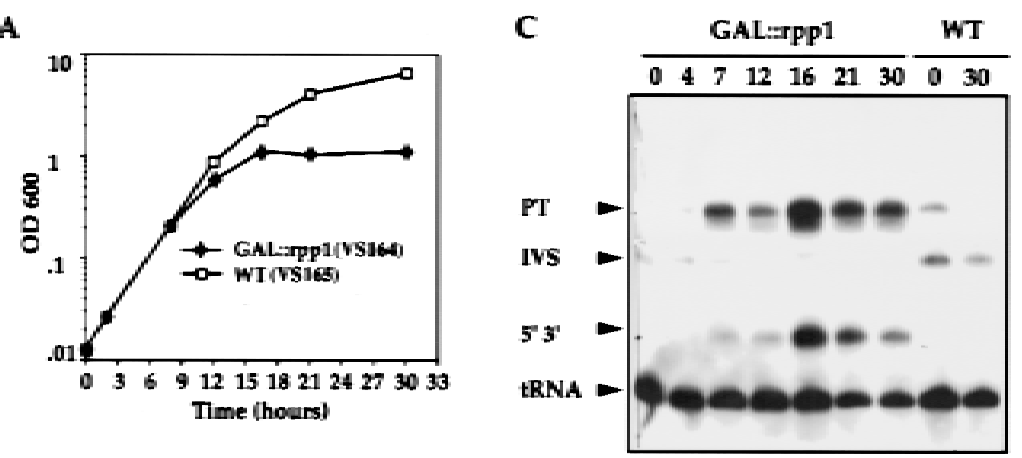

B

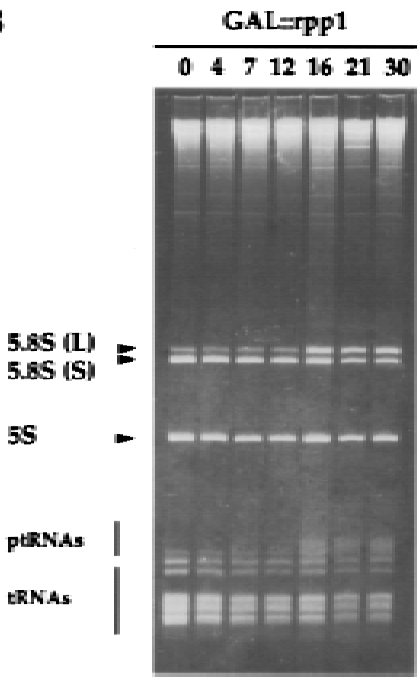

D

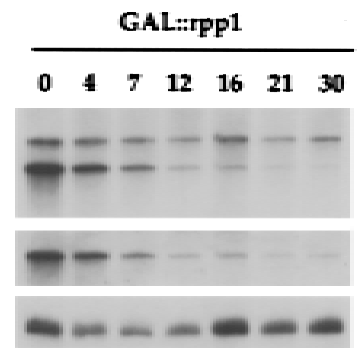


of the pre-tRNA ${ }^{\text {Leu3 }}$ (data not shown), showed an accumulation of tRN A that was unprocessed at both termini. After growth of the GAL::rppl strain in gl ucose for $12 \mathrm{hr}$, $5^{\prime}$ and $3^{\prime}$ unprocessed ptRNA ${ }^{\text {Leu3 }}$ accumulated to approximately the same level as that of mature tRN A. The level of pretRN A ${ }^{\text {Leu3 }}$ that was unspliced but processed at both ends was reduced correspondingly. These results showed that the sequentially ordered removal of the $5^{\prime}$ leader sequence, the $3^{\prime}$ trailing sequence, and finally the intron of ptRN $A^{\text {Leu3 }}$, is impaired in Rppl-depleted cells. As this phenotype is observed in the RN ase P RN A mutants, rpr1 and rpr1 (T 315 1 T 307) (Lee et al. 1991; Chamberlain et al. 1996b), we conclude that Rppl is an essential protein subunit of the catalytically active RNase P complex in vivo.

Rppl is required for accumulation of RNase $P$ and RNase MRP RNAs

We investigated further the effect of Rppl depletion on the steady-state levels of RN ase P and RN ase MRP RNAs to ascertain if cells lacking Rppl shared phenotypic traits with previously described conditional lethal mutants of Pop1, Pop3 and Pop4, proteins that associate with both RN Ps. Depletion of Rppl results in a decrease of the steady-state levels of RN ase $P$ and $R N$ ase MRP RNAs (Fig. 5D). However, the RPRI RN A precursor does not appear to decrease to the same extent as mature RPR1 RNA, even after $30 \mathrm{hr}$ of Rppl depletion. As with Pop4 depletion (Chu et al. 1997), mature RPR1 RNA is not detectable after $21 \mathrm{hr}$ of Rppl depl etion. In contrast, depletion of Pop3 does not affect steady-state levels of these RNAs, whereas in popl-1 steady-state levels of both mature and precursor RPR1 RNAs and N MEI RNA are reduced (Lygerou et al. 1996a; Chu et al. 1997; Dichtl and Tollervey 1997). These data suggest that the amount of Rppl is correlated with the maturation and stability of RPR 1 and stability of NME1 in vivo. Both RN As may be found within a large RNP complex, or alternatively, Rppl may be shared between the two RN P particles in vivo.

Rppl is required for processing of the $35 \mathrm{~S}$ prRNA

In S. cerevisiae and other eukaryotes, rRNA is transcribed as a 35 S precursor RNA that contains within it the sequences for three of the four rRN A molecules (18S, 5.8S, and 25-28S). Subsequent processing and nucleotide modifications invol ving endonucl eolytic and exonucleoIytic cleavages and methylation generate mature rRNA (for review, see Eichler and Craig 1994; Venema and Tollervey 1995; Tollervey 1996). We examined the fidelity of rRN A processing in Rppl-depl eted cells to determine if defects in this pathway were similar to those described previously for mutants that affect RN ase $P$ and RN ase MRP (Shuai and Warner 1991; Lindahl et al. 1992; Schmitt and Clayton 1993; Chamberlain et al. 1996b; Lygerou et al. 1996a; Chu et al. 1997; Dichtl and Tollervey 1997). rRNAs were analyzed by gels stained with ethidium bromide and by N orthern analysis with oligonucleotide probes (Table 2 ) to detect various prRNA species (see Figs. 5B and 6).

On depletion of the Rppl protein, we observed multiple defects in rRN A processing at the $A 0$ and $A 1$ sites in the 5' external transcribed sequence (5' ETS), at the $A 2$ and $A 3$ sites within the internal transcribed sequence

Table 2. Oligonucleotides used in this study

Oligo 1: 5'-CAGCAGAGAGACCCGA-3'

Oligo 2: 5'-ACTATCTTAAAAGAAGAAGC-3'

Oligo 3: 5'-GAATTACCACGGTTATACC-3'

Oligo 4: 5'-GCACAGAAATCTCTCACC-3'

Oligo 5: 5'-ATGAAAACTCCACAGTG-3'

Oligo 6: 5'-CCAGTTACGAAAATTCTTG-3'

Oligo 7: 5'-CGCATTTCGCTGCGTTCTTCATCG-3'

Oligo 8: 5'-ACAGAATGTTTGAGAAGGAAATG-3'

Oligo U6: 5'-TCATCCTTATGCAGGG-3'

Oligo mtRNA: 5'-GCATCTTACGATACCTG-3'

Oligo ItRN A: 5'-CCAAACAACCACTTATTTGTTGA-3'

Oligo itRNA: 5'-CACAGTTAACTGCGGTC-3'

Oligo T7MRP: 5'-GGGAATTCGAAATTAATACGACTCACTATAGAATCCATGACCAAAGAATCGTCA-3'

Oligo 3' MRP: 5'-TCCCCCGGGTGAATCCATGGACCAAGA-3'

Oligo T7ITS14: 5'-GGGAATTCGAAATTAATACGACTCACTATAGACACTGTGGAGTTTTCATATC-3'

Oligo 3' ITS14: 5'-GGGGATCCTTAAAATTTCCAGTTACGAAAATTC-3'

Oligo T7ITS16: 5'-GGGAATTCGAAATTAATACGACTCACTATAGGCCAAACGGTGAGAGATTTCTG-3'

Oligo 3' ITS16: 5'-GGGGATCCACTTTAAGAACATTGTTCGCCT-3'

Oligo MYC5: 5'-GCGGAATGCTGGAACAGAAACTTATT-3'

Oligo T 7ITS16: 5'-GGGAATTCGAAATTAATACGACTCACTATAGGCCAAACGGTGAGAGATTTCTG-3'

Oligo 3' ITS16: 5'-GGGGATCCACTTTAAGAACATTGTTCGCCT-3'

Oligo MYC3: 5'-ACCAGCATTCCCAAATCTTCTTCAGA-3'

Oligo 5 GAL30: 5'-GGGGATCCGCATTATAGAACCGAGAATGC-3'

Oligo 3 GAL30: 5'-GGTCTAGAGATCCCCAAATTTTTTTGTCT-3' 


\section{Stolc and Altman}

(ITS1), and at the E and/or C2 sites within the internal transcribed sequence 2 (ITS2) (Fig. 6). A nalysis of lowmolecular-weight RNA showed that synthesis of $5.8 \mathrm{~S}(\mathrm{~S})$ rRN A was reduced in an Rppl-depleted strain, whereas
5.8S(L) rRNA increased (Fig. 5B). The altered ratio between $5.8 \mathrm{~S}(\mathrm{~L})$ and $5.8 \mathrm{~S}(\mathrm{~S})$ suggests a defect in cleavage at the A3 site in the ITS1 and/or other processing sites required for maturation of $5.8 \mathrm{~S}$ rRNA in vivo (Schmitt

A

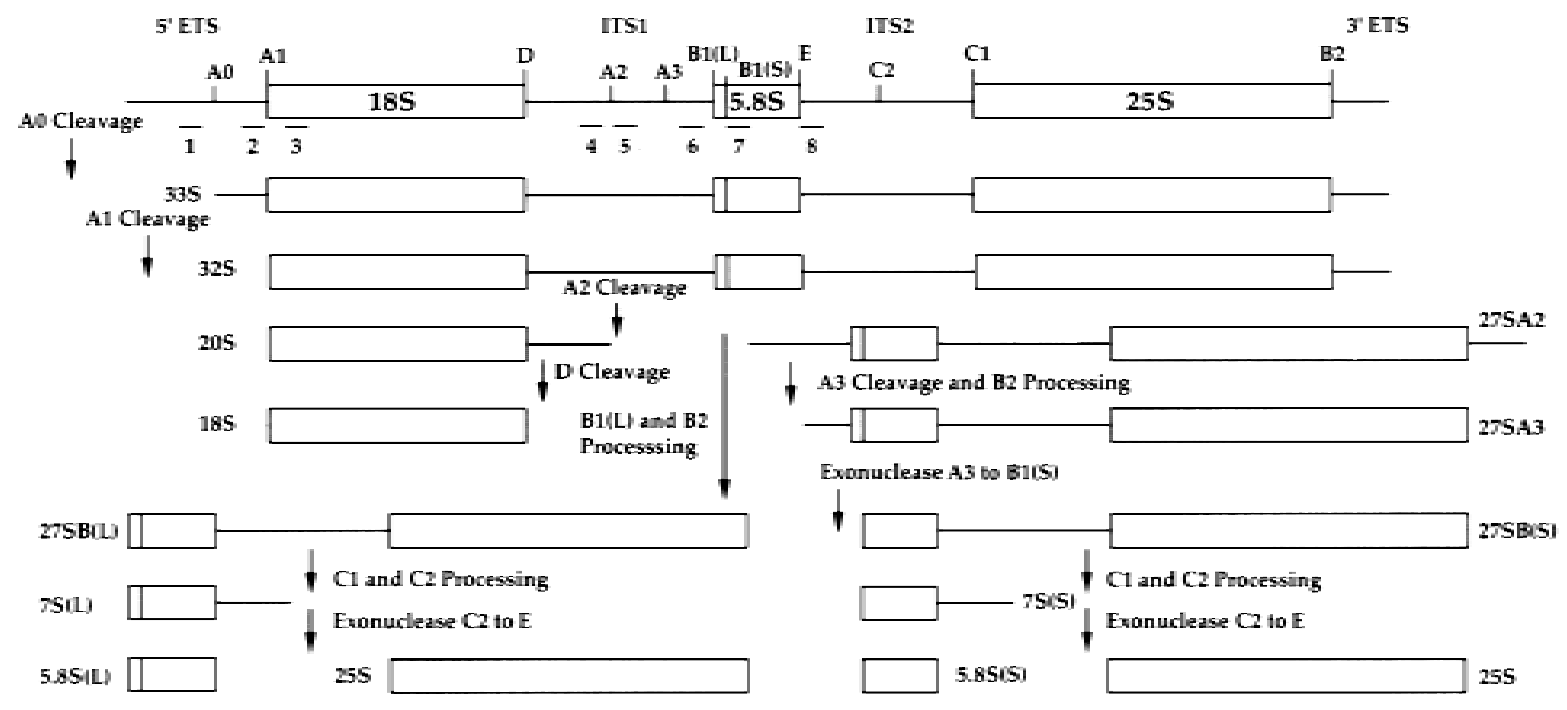

B

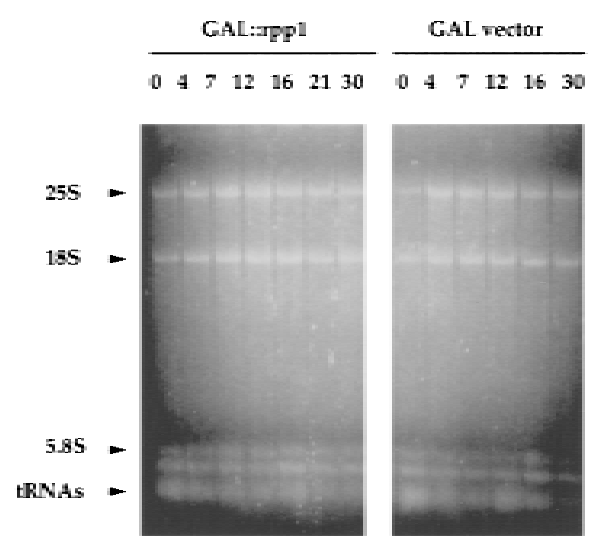

C

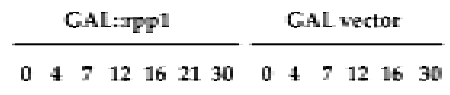

$\mathrm{D}$

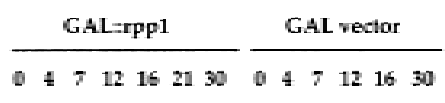

$\mathbf{E}$
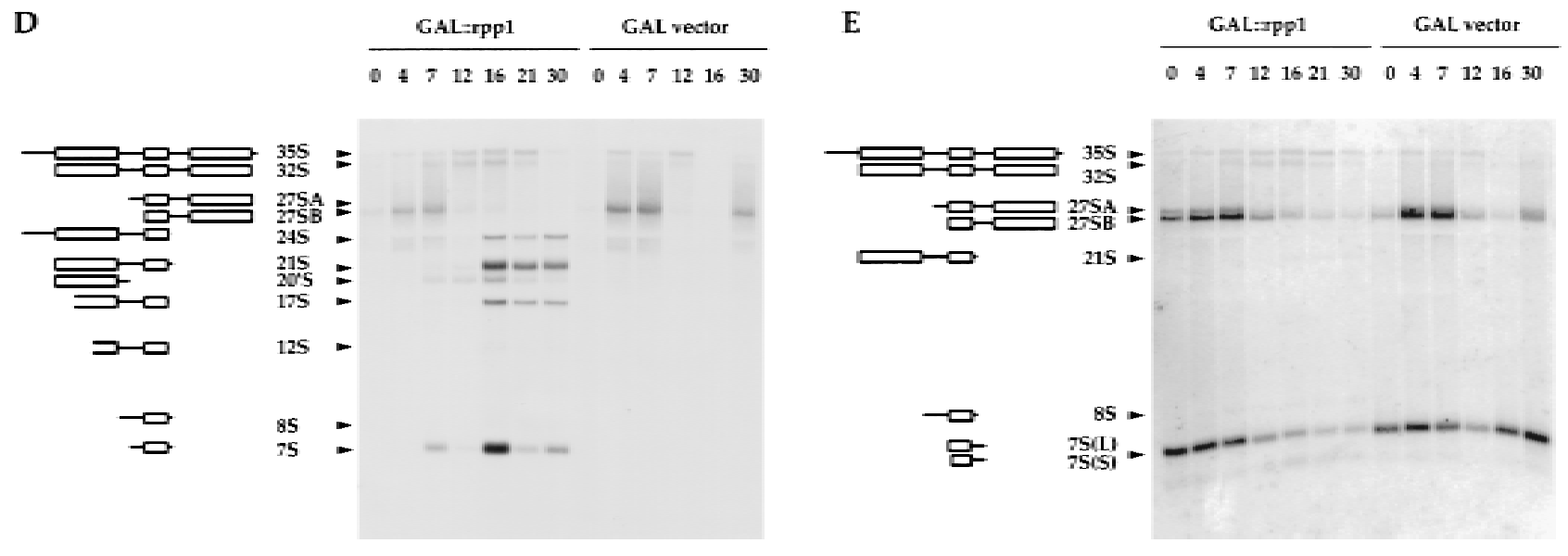

Figure 6. (See facing page for legend.) 
and Clayton 1993; Henry et al. 1994). Figure 6D shows an accumulation of a 7S precursor to 5.8S rRNA after $7 \mathrm{hr}$ of Rppl depletion. This precursor is predicted to have its $5^{\prime}$ end at the A2 site of ITS1 and its $3^{\prime}$ end at the $3^{\prime}$ end of $5.8 \mathrm{~S}$ rRNA. If this prediction is proven correct, then we will be able to conclude that there is a defect in cl eavage at the A 3 site under the conditions we used.

In addition, two large precursors of the 18S rRN A accumulated at later times in Rppl-depleted cells (Fig. 6C,D). The 245 rRN A precursor that contains both 5' ETS and IT S1 sequences shows defects in cleavage at the $A 0, A 1, A 2$, and $A 3$ processing sites, and the $21 S$ rRN $A$ precursor shows defects in cleavage and processing at the $A 2$ and $A 3$ processing sites in ITS1 and at the $E$ site in ITS2 (Fig. 6C,D). The $17 \mathrm{~S}$ and $12 \mathrm{~S}$ rRNA degradation intermediates represent sequences with fragmented $5^{\prime}$ ends within the 18S rRNA (Fig. 6C,D; Allmang et al. 1996a). Figure 6E shows depletion of the $7 S(S)$ and $7 S(L)$ precursors to $5.8 \mathrm{~S}$ rRN A, depletion of the 27SA and 27SB precursors to $25 \mathrm{~S}$ rRNA, and accumulation of an $8 \mathrm{~S}$ rRNA precursor of the 5.8S rRNA, which contains $5^{\prime}$ extended sequences from ITS1 and 3' extended sequences from ITS2. These intermedi ates indi cate defects in cleavage at the $A 3$, and $E$ and/or $C 2$ processing sites of the ITS1 and ITS2, respectively. AII probes al so detected a moderate accumulation of the 35S rRN A primary transcript and probes 2-7 also detect the 32S precursor rRN A (Fig. 6C-E; data not shown). Despite these defects the steady-state levels of the 18S rRNA and 25S rRNA remained unchanged (Fig. 6B), suggesting del ayed processing of 35S rRNA in the absence of Rppl.

Our results show that Rppl is required for processing of 35 S rRN A in the 5' ETS, ITS1, and IT S2. Interestingly, some of the same processing reactions have been shown to be dependent on snoRN Ps, RN ase M RP, and RN ase P, and the same stable rRN A degradation intermediates accumulate in cells deficient in snoRNP components (Shuai and Warner 1991; Lindahl et al. 1992; ChamberIain et al. 1996b; Venema and T ollervey 1996). However, none of the known proteins that associate with these
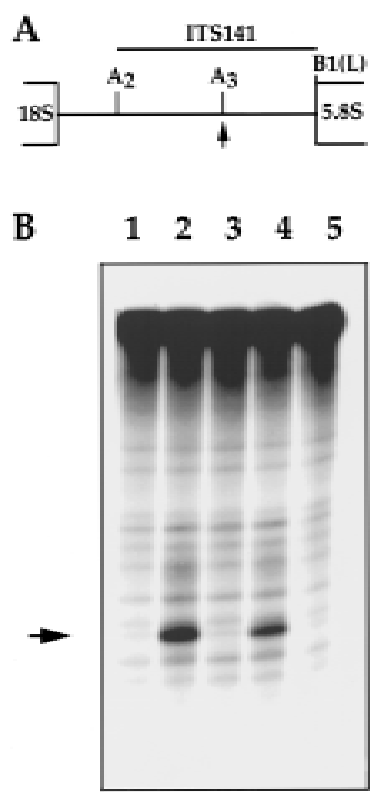

Figure 7. Processing of prRNA by Rppl immunoprecipitates. (A) Position of the ITS141 rRNA substrate relative to the 355 rRN A precursor [ $5^{\prime}$ end is at $A 2$ site and $3^{\prime}$ end is at $B 1(L)$ site]. (B) Uniformly labeled rRN A transcript, ITS141 (see Materials and Methods), was incubated with $3 \times$ myc-Rppl immunoprecipitates derived from the same immunoprecipitates as in Fig. $3 \mathrm{~A}$ for $2 \mathrm{hr}$ at $37^{\circ} \mathrm{C}$, and then fractionated on a $8 \%$ polyacrylamide/ 7 M urea gel. (Lanes 1-4) ITS141 rRN A, plus IgG-agarose pellets to which are bound immunoprecipitated RN ase $P$ and RN ase MRP RNAs as in Fig. 3A. (Lane 5) ITS141 rRNA. The arrow indicates the position of two cleavage products of almost identical size from the ITS1 rRN A transcripts. The site of cleavage corresponds to the region of the $A 3$ site in the internal transcribed sequence 1 (ITS1) (Lygerou et al. 1996).

RN P particles exhibit the same global defects in prRN A and ptRN A processing found in Rppl-depleted cells. Interestingly, depletion of the snoRNP protein, Rrp5, results in striking similarities to Rppl-depleted cells with

Figure 6. Effects of Rppl depletion on the processing of 35S prRNA. (A) Schematic plan of the rRN A processing pathway (Venema and Tollervey 1995). Steady-state levels of rRNA, prRNA intermediates, and aberrant rRNA species were detected by ethidium bromide staining and by N orthern hybridization with oligonucleotide probes 1-7. (B) T otal RN A extracted from VS164 and VS165 was obtai ned after transfer from gal actose-containing to glucose-containing medium at the times indicated, and separated in a I.2\% agarose gel stained with ethidium bromide. Arrows indicate $25 \mathrm{~S}$ rRN A, 18S rRN A, $5.8 \mathrm{~S}$ rRN A, and tRN As. (C-E) The gel shown in B was transferred to a positively charged nylon membrane (Boehringer $\mathrm{M}$ annheim) by capillary diffusion and hybridized with $\gamma^{-32}$-label ed ol igonucleotide probes 4-6 (see M aterials and M ethods). Oligonucleotide 4 (C) is complementary to the ITS1, between $3^{\prime}$ end of $18 \mathrm{~S}$ rRNA and the A2 site (position 157-180), oligonucleotide 5 (D) is complementary to the ITS1, between A2 and A3 sites (position 119-236), and oligonucleotide 8 (E) is complementary to the ITS2, between the $3^{\prime}$ end of 5.8S rRNA and C2 site (position -3 to +21). The 24S precursor rRNA is predicted to extend from the $5^{\prime}$ end of the $5^{\prime}$ ETS to the $3^{\prime}$ end of $5.8 \mathrm{~S}$ rRN A, and represents a product of the $35 \mathrm{~S}$ rRN $A$ precursor that is cleaved in ITS2 in the absence of cleavage at the $A 0, A 1, A 2$, and $A 3$ sites. The $21 S$ precursor rRN $A$ appears to be comprised of rRN A species that are predicted to extend from the $5^{\prime}$ end of $18 \mathrm{~S}$ rRN A to the $3^{\prime}$ end of 5.8S rRN A, and also have $3^{\prime}$ ends that extend $3^{\prime}$ to the $3^{\prime}$ end of $5.8 \mathrm{~S}$ rRN A, and may be heterogeneous. The $20^{\prime} \mathrm{S}$ rRN A species is predicted to extend from the $5^{\prime}$ end of $18 \mathrm{~S}$ rRN A to the region of the A3 site in the ITS1. The $17 \mathrm{~S}^{\prime}$ and $12 \mathrm{~S}^{\prime}$ aberrant rRN A species represent stable degradation intermediates, which may have fragmented $5^{\prime}$ ends that correspond to sequences within $18 \mathrm{~S}$ rRN A and $3^{\prime}$ ends close to the $3^{\prime}$ end of 5.8S rRN A. The 8S rRN A species is predicted to extend from the $5^{\prime}$ end of ITS1 to the $3^{\prime}$ extended ends of 5.8S rRNA. The 7S RNA is the precursor of the 5.8S rRN A, which is predicted to extend from the region of the A2 site in the ITS1 to the $3^{\prime}$ end of 5.8S rRNA. 
respect to defects of prRNA processing (Venema and Tollervey 1996; see Discussion). Therefore, we suggest that RN ase $P$ interacts functionally with RN ase MRP and perhaps other snoRNPs in the processing of rRNA in yeast.

\section{Processing of precursor rRNA by Rppl} immunoprecipitates

We tested whether Rppl is associated directly with prRN A processing activity by in vitro cleavage assay of two fragments of the $35 \mathrm{~S}$ rRN A. We assayed cleavage in vitro by resuspending $3 \times$ myc-Rppl-containing immunoprecipitates with two fragments of the 355 precursor rRN A, IT S1.603 (Chamberlain et al . 1996b) and IT S1.141 (similar to Lygerou et al. 1996a). Both prRN A substrates overlap the ITS1 (see Fig. 7A, and M aterials and M ethods). Rppl immunoprecipitates, which contained both RN ase $P$ and RN ase M RP RN As, cleaved ITS1.141 (Fig. 7B) and IT S1.603 (data not shown) in the region of the A 3 processing site. This result is consistent with, but does not rigorously prove, the observed defects in processing the 35S rRNA on depletion of the Rppl protein in vivo. However, $3 \times$ myc-Rppl immunoprecipitates that were washed extensively with high ionic buffer (see Material and $M$ ethods) failed to cleave the prRN A substrates but cleaved ptRNAs in vitro (data not shown). These results suggest that in addition to RN ase MRP, there is a di rect role for an RN ase P-containing complex in rRNA processing in vivo.

\section{Discussion}

We have cloned a gene encoding a protein subunit of nuclear RN ase P from S. cerevisiae based on its homology to human Rpp30. Yeast Rpp1 is homologous to the human scleroderma autoimmune antigen, Rpp30, which was described previously as an autoantigen that copurifies with at least six other Rpp protein subunits of human RN ase P-Rpp14, Rpp20, Rpp25, Rpp30, Rpp38, and Rpp40 (Eder et al. 1997). Using computer database searches (blastp and tblastn algorithms), we compared the predicted amino acid sequences of human Rpp proteins with the $S$. cerevi siae genome database. This analysis reveal ed that Rppl is one of three yeast proteins with amino acid sequence similarity to the human Rpp proteins. A second such yeast protein is Pop4, a subunit of yeast RN ase P and RN ase MRP (Chu et al. 1997), which is related in amino acid sequence to a previously uncharacterized human Rpp protein, Rpp29 (P. Eder, N. Jarrous, and S. Altman, unpubl.). The third yeast, protein, Rpp2, shares amino acid similarity with Rpp20 (V. Stolc and S. Altman, unpubl.)

$\mathrm{Rppl}$ is a small basic protein with a predicted molecular mass of $32.2 \mathrm{kD}$ and $\mathrm{pl}$ 9.76. It does not have any previously identified RNA-binding domains. In vitro, Rppl remains associated with the mature $R N$ ase $P$ RN A and RN ase $P$ activity, even in buffers of high ionic strength. Rppl also associates with RN ase MRP RNA and an rRNA processing activity (cleavage at the A3 site), ascribed previously to RN ase MRP (Lygerou et al. 1996a). However, in contrast to RN ase $P, R N$ ase MRP RN A and the rRN A processing activity can be separated from Rppl after high-salt washes. Furthermore, the human Rpp30 does not associate with RN ase M RP (N. Jarrous and $S$. Altman, unpubl.) Whether yeast RN ase $P$ cleaves the prRNA substrates directly in vivo is unknown. Proposals for the secondary structure of ITSI that are based on phylogenetic analysis and chemical mapping of ITS1 (Van N ues et al. 1994; Allmang et al. 1996b) and computational folding of the ITS1.141 prRN A substrate, do not show a common structural feature of an RNase P substrate (a helical segment at the junction of a single-stranded region; Altman et al. 1995). Moreover, prRNA substrates used in this study are not cleaved at the A3 site in vitro by reconstituted E. coli RN ase $P$ (V. Stol $c$ and S. Altman, unpubl.), which has a broader substrate specificity than eukaryotic RN ase P (Yuan and Altman 1994). Therefore, in vivo, yeast Rpp1 may be a shared subunit of a large RN P complex containing both RNase $\mathrm{P}$ and RN ase MRP, and perhaps other snoRN Ps.

On depletion of Rppl in vivo, we found a defect in ptRN A processing, an indication that Rppl is associated with RNase $P$ activity. Surprisingly, we also found an rRNA processing defect characterized by the absence of cleavage at the $A 0$ and $A 1$ sites in the $5^{\prime}$ ETS, and the $A 2$ and $A 3$ sites in ITS1, and at the $E$ and/or $C 2$ sites in ITS2 of the primary 35S rRN A transcript. To our knowledge, Rppl is the only RN ase P or RN ase MRP protein, that on depletion simultaneously inhibits cleavages at all of these major processing sites of 35S rRNA and is required for ptRNA processing. $M$ oreover, processing of prRNA at sites $A 0, A 1, A 2, A 3, E$, and/or C2 may be coordinated by RNase $P$, as depletion of RN ase MRP RNA al one results only in defects at the A 3 site (Schmitt and Clayton 1993).

A part from RN ase M RP, other essential snoRN Ps may be involved directly in the mechanism of rRN A processing (for recent reviews, see Eichler and Craig 1994; Venema and Tollervey 1995; Tollervey 1996). In contrast to the Rppl phenotype, depletion- or temperature-sensitive alleles of these snoRNAs or their associated proteins show no defect in ptRNA processing and, with the exception of snoRN P protein Rrp5, no single component is defective for processing at all of the processing sites in the 5' ETS, ITS1, and ITS2. For example, Garlp, N oplp, Sof1p, as well as snoRN A U3, U 14, and snR30-depleted cells, and strains lacking snR 10 are defective at $A 0, A 1$, and $A 2$ sites without detectable inhibition of the $A 3$ site (Tollervey 1987; Li et al. 1990; Hughes and Ares 1991; Tollervey et al. 1991; Girard et al. 1992; Jansen et al. 1993; Morrissey and Tollervey 1993). The prRN A processing phenotype of Rrp5-depleted strains differs from that of Rppl in that it is defective in maintaining accumulation of $25 \mathrm{~S}$ rRN A, $18 \mathrm{~S}$ rRN A, and relative levels of rRNA intermediates (Venema and Tollervey 1996). Interestingly, as in Rppl-depl eted cells, cleavage at the A3 site is also defective in Pop1, Pop3, Pop4, and RN ase MRP (NME1) conditional mutants (Shaui and Warner 
1981; Lindahl et al. 1992; Schmitt and Clayton 1993; Lygerou et al. 1996a; Chu et al. 1997; Dichtl and Tollervey 1997). Therefore, although Rppl shares rRN A processing defects with known RN ase P, RN ase MRP, and snoRN Ps, it is the only described protein that has both ptRN A processing defect as well as rRN A processing defects at the $A 0, A 1, A 2, A 3$, and $E$, and/or $C 2$ processing sites.

\section{Materials and methods}

Strains, media, and general procedures

S. cerevisiae strains used in this work are listed in Table 1. The composition of the media with appropriate nutrients for plasmid maintenance and S. cerevisiae growth and handling techniques were used as described (Guthrie and Fink 1991). Unless stated otherwise, all techniques for manipulating DNA, RNA, and ol igonucl eotides were performed according to standard procedures (Sambrook et al. 1989). The identities of all constructs were verified by sequence analysis. Oligonucleotides used in this study are listed in Table 2.

\section{Gene disruption}

A genomic clone spanning the RPP1 locus was identified using the S. cerevisiae Genome Database (SGD) and obtained from the American Tissue Culture Collection (ATCC) as cosmid 8025. Clone 8025 was sequenced previously (Johnston et al. 1994). A 1.4-kb BamHI-Xbal fragment encoding the RPP1 gene was subcloned from cosmid 8025 into pBluescript (SK) vector (Stratagene) cut with BamHI-Xbal to generate pRPP1SK. The RPP1 gene was disrupted by replacing a $0.6-\mathrm{kb} \mathrm{N}$ col-N del fragment with the LEU 2 gene, thereby deleting $65 \%$ of the coding sequence. The rppl::LEU 2 construct was integrated at the RPP1 genomic locus in diploid strain JN 161 (VS161) and correct replacement of one allele was verified by PCR digest analysis: Oligonucleotides 5GAL30 and 3GAL30 were used to amplify genomic DNA isolated from VS161, the resulting PCR-amplified fragment $(2.7 \mathrm{~kb})$ encoding LEU 2 and flanking sequences of Rppl was mapped with restriction enzymes. The heterozygous RPP1/rpp1::LEU2 strain (VS161) was sporulated and tetrad analysis showed a 2:2 segregation for cell viability. Dissections were performed on 20 tetrads. The same disruption and analysis was performed for strain VS163, which was disrupted with the rpp1::LEU 2 construct.

\section{Construction of plasmids}

To generate myc-epitope-tagged RPP1, three myc epitope domains $(3 \times$ myc) were PCR-amplified from the $3 \times$ myc-SEC 8 construct (TerBush and Novick 1996) using oligonucleotides MYC5 and MYC3, and then cut with Bsml. The PCR fragment was subcloned into the Bsml site of pRPPISK plasmid to generate $\mathrm{p3} \times$ myc-RPP1SK. A $1.5-\mathrm{kb}$ BamHI-Xbal fragment from p3 $\times$ myc-RPP1SK was subcloned into pRS316 plasmid to generate pRS316-3 × myc::RPP1. The coding sequence of RPP1 was PCR-amplified from pRPP1SK using oligonucleotides 5GAL30 and 3GAL30, cut with BamHI and $\mathrm{Xhol}$, and subcloned into modified pY Cp33 vector that contained the GAL1-10 promoter to generate pYCp-GAL::rpp1. To generate rRN A ITS1 substrate, ITS1.141 (similar to Lygerou et al. 1996a), oligonucleotides T 7ITS14 and 3' ITS14 were used to PCR-amplify yeast genomic DN A and then the 141-bp fragment was cloned into EcoRI and BamHI sites in pUC19 ( $\mathrm{New}$ England Biolabs). To generate
rRN A ITS1 substrate, ITS1.603 (Chamberlain et al. 1996b), oligonucleotides T 7ITS16 and 3' ITS16 were used to PCR amplify yeast genomic DNA and the amplified fragment was subsequently subcloned into pU C 19 the same way as for the IT S1.141 fragment. The NME-coding sequence was amplified by PCR from yeast genomic DNA using T7MRP and 3' MRP oligonucleotides, and subcloned into EcoRI and Smal sites of pUC19 to generate $\mathrm{PUCT}$ 7MRP.

\section{Strain construction}

The diploid strain heterozygous for the RPP1 deletion (VS161) was transformed with pRS316::3 $\times$ myc-Rpp1 plasmid and sporulated. After sporulation and dissection, spores disrupted for RPP1, but harboring the plasmid encoded $3 \times$ myc-Rppl fusion protein, were viable. Only two haploid cells (VS162A' and VS162C'), derived from sporulation of a single tetrad, were viable after the loss of the pRS316- $3 \times$ myc-RPP1 plasmid during selection on plates that contain 5-fluoro-orotic acid (5-FOA): These haploids were Leu-, showing that they had lost the pRS316-3 ×-RPP1 plasmid and had the wild-type RPP1 allele. The other two haploids (VS162B and VS162D) were not viable without the pRS316-3 $\times$ myc-RPP1 plasmid during selection on 5-FOA plates and were $\mathrm{Leu}^{+}$, showing that they had the $3 \times$ myc-tagged RPP1 allele. The same results were obtained after dissection of five additional tetrads. The growth rate of two haploid rpp1:LEU 2 cells (VS162B and VS162D), which depend on a low-copy-number episomal plasmid encoding the $3 \times$ mycRPP1 (pRS316-3 $\times$ myc-RPP1) for viability, was identical to that of the wild-type haploid cells (VS162A and VS162C).

VS163 was transformed with pYCp-GAL::rppl plasmid (VS164) or a control plasmid, pYCp-GAL (VS165), sporulated and germinated on medium that contained galactose. Four viable spores were obtained from several independent tetrads and the presence of the plasmid-encoded GAL::rppl fusion gene was verified on $\mathrm{ura}^{-}$and $\mathrm{leu}^{-}$plates containing gal actose.

\section{Immunoprecipitation}

Extracts were prepared by lysis of yeast cells $(25 \mathrm{ml}$, $\mathrm{OD}_{600}=0.5$ ) with gl ass beads (Guthrie and Fink 1991). Extracts were clarified by centrifugation three times at $15,000 \mathrm{~g}$ for 10 $\mathrm{min}$. The final supernatants were used in immunoprecipitations by adding $4 \mu \mathrm{g}$ of $9 \mathrm{E} 10$ antibody to the protein extract derived from spores VS162A', VS162B, VS162C', and VS162D, and incubated for $2.5 \mathrm{hr}$, foll owed by addition of $50 \mu \mathrm{l}$ of $100 \mathrm{mg} / \mathrm{ml}$ of anti-mouse IgG (whole molecule) agarose (Sigma) in IP150 buffer (150 mM KCl, $10 \mathrm{~mm}$ Tris-Cl (pH 7.9), 0.1\% N P-40, and $0.1 \% \mathrm{NaN}_{3}$ ). Pellets were washed five times with IP150 or IP600 (same composition as IP150, except $600 \mathrm{~mm} \mathrm{KCl}$ ). RN A was extracted from the immunoprecipitated beads by adding $100 \mu \mathrm{l}$ of IPR buffer ( $100 \mathrm{~mm}$ Tris-Cl at pH 7.5, $100 \mathrm{~mm}$ EDTA at $\mathrm{pH} 8.0,150 \mathrm{~mm} \mathrm{~N} \mathrm{aCl}, 1 \% \mathrm{SDS}$ ), followed by two extractions with phenol and one extraction with phenol/chloroform/isoamylalcohol solution (25:24:1). RNA was precipitated with ethanol.

\section{Assays for RNase $\mathrm{P}$ activity and rRNA processing activity}

IgG-agarose pellets, to which are bound immunoprecipitated RN ase P and RN ase MRP RNAs, were washed with IP150 and incubated with labeled ptRN $A^{\text {Ser }}$ (Drainas et al. 1989) for 30 $\min$ at $37^{\circ} \mathrm{C}$ in $1 \times \mathrm{BB}(10 \mathrm{~mm}$ HEPES at $\mathrm{pH} 8.0,400 \mathrm{~mm}$

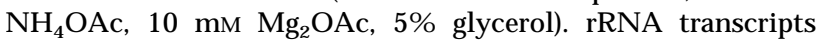
ITS1.141 and ITS603 (Chamberlain et al. 1996b) were incubated with IgG pellets to which are bound immunoprecipitated 
RN ase $P$ and RN ase M RP RN As (washed with IP150) for $2 \mathrm{hr}$ at $37^{\circ} \mathrm{C}$ in $1 \times P M B(20 \mathrm{~mm}$ Tris- $\mathrm{HCl}$ at $\mathrm{pH} 8.0,10 \mathrm{~mm} \mathrm{M} \mathrm{gCl} 2,1 \mathrm{~mm}$ EDTA, $50 \mathrm{~mm} \mathrm{KCl}, 2$ units of RN asin, and $50 \mathrm{mg} / \mathrm{ml}$ of BSA). IgG pellets, to which is bound RN ase P RNA, were washed with IP600 and incubated with either ptRN A ${ }^{\text {Ser }}$, ITS141, or ITS603 as above. The tRNA substrate, ITS141, and ITS603 rRNA substrates were labeled uniformly with [ $\left.{ }^{32} \mathrm{P}\right] \mathrm{GTP}(3000 \mathrm{mCi} /$ mmole, Amersham) and purified on an $8 \%$ polyacrylamide/ $7 \mathrm{M}$ urea gel. The assays were performed with $0.5 \mathrm{~nm}$ ptRN A, $3.2 \mathrm{~nm}$ ITS141 RN A, or $0.5 \mathrm{~nm}$ ITS603 RNA. The RN A products were fractionated on an $8 \%$ polyacrylamide/ $7 \mathrm{M}$ urea gel.

\section{RNA analysis}

Total RNA was isolated by disruption of cell pellets $(25 \mathrm{ml}$, $\mathrm{OD}_{600}=0.5$ ), resuspended in AE buffer [50 mM NaAc at pH 5.3, $10 \mathrm{~mm}$ EDTA, $10 \mathrm{~mm}$ RN ase inhibitor, vanadyl ribonucleoside complex (GIBCO BRL)] and equal volume of phenol and chloroform, with glass beads at $65^{\circ} \mathrm{C}$ for $15 \mathrm{~min}$. Phenol/chloroform extractions were repeated four times at $65^{\circ} \mathrm{C}$ for $15 \mathrm{~min}$, followed by an extraction with chloroform at $25^{\circ} \mathrm{C}$ and ethanol precipitation. Northern hybridization was performed as described previously (Guerrier-Takada et al. 1995). All oligonucleotides were end-labeled with T4 polynucleotide kinase (New England Biolabs) and $\left[\gamma^{32}{ }^{32}\right]$ ATP (Amersham). NME1 EcoRI-Smal DN A fragment from pUCT 7M RP and EcoRI-Smal DNA fragment from pScRNAP (Lee et al. 1991) were labeled uniformly with $\left[{ }^{32} \mathrm{P}\right] \mathrm{dCTP}$ (Amersham).

\section{Acknowledgments}

We thank Y. Barral, J. N ovak, S. Reck-Peterson, B. Rockmill, S. Roeder, and A. Smith for yeast strains and hel pful advice, D.R. TerBush and P. N ovick for yeast strains and $9 \mathrm{E} 10$ antibody, K. Ross for the GAL plasmid, and P.S. Eder, N. Jarrous, V. Gopalan, and C. Guerrier-Takada for discussion and useful comments. We are grateful to $M$. Snyder and several other colleagues for a critical reading of the manuscript. V.S. was supported by a pre doctoral training grant in cell biology from the U.S. Public Health Service (U.S. PHS) to Yale University. Research in the laboratory of S.A. was funded by grant GM -19422 from the U.S. PHS.

The publication costs of this article were defrayed in part by payment of page charges. This article must therefore be hereby marked "advertisement" in accordance with 18 USC section 1734 solely to indicate this fact.

\section{References}

Alifano, P., F. Rivellini, C. Piscitelli, C.M. Arraiano, C.B. Bruni, and M.S. Carlomagno. 1994. Ribonuclease E provides substrates for ribonuclease $\mathrm{P}$-dependent processing of a polycistronic mRN A Genes. \& Dev. 8: 3021-3031.

Allmang, C., Y. Henry, J.P. M orrissey, H. Wood, E. Petfalski, and D. Tollervey. 1996a. Processing of the yeast pre-rRNA at sites $A(2)$ and $A(3)$ is linked. RNA 2: 63-73.

Allmang, C., Y. Henry, H. Wood, J.P. Morrissey, E. Petfalski, and D. Tollervey. 1996b. Recognition of cleavage site A(2) in the yeast pre-rRNA. RNA 2: 51-62.

Altman, S., L. Kirseborm, and S. Tal bot. 1993. Recent studies of ribonuclease $P$. FASEB J. 7: 7-14

- - - 1995. Recent studies of RN ase P. In tRNA: Structure biosynthesis and function (ed. D. Soll and U.L. RajBhandary), pp. 67-78. American Society for Microbiology, Washington, DC.
Altschul, S.F., W. Gish, W. Miller, E.W. Myers, and D.J. Lipman. 1990. Basic local alignment search tool. J. Mol. Biol. 215: 403-410.

Bothwell, A.L.M., B.C. Stark, and S. Altman. 1974. Ribonuclease $P$ substrate specificity: Cleavage of a bacteriophage $\phi /$ 80-induced RN A. Proc. Natl. Acad. Sci. 73: 1912-1916.

Bothwell, A.L.M., R.L. Garber, and S. Altman. 1976. N ucleotide sequence and in vitro processing of a precursor molecule to Escherichia coli 4.5S RN A. J. Biol. Chem. 251: 7709-7716.

Brow, D.A. and C. Guthrie. 1990. Transcription of a yeast U 6 SnRN A gene requires a polymerase III promoter element in a novel position. Genes \& Dev. 4: 1345-1356.

Chamberlain, J.R., A.J. Tranguch, E. Pagan-Ramos, and D.R. Engelke. 1996a. Eukaryotic nuclear RN ase P: Structures and function. Prog. Nucleic Acid Res. Mol. Biol. 55: 87-119.

Chamberlain, J.R., E. Pagan-Ramos, D.W. Kindelberger, and D.R. Engelke. 1996b. An RN ase P RNA subunit mutation affects ribosomal RNA processing. Nucleic Acids Res. 24: 3158-3166.

Chang, D.D. and D.A. Clayton. 1987. M ouse RN ase M RP RN A is encoded by a nuclear gene and contains a decamer sequence complementary to a conserved region of mitochondrial RNA substate. Cell 56: 131-139.

Cherry, J.M., C. Adler, C. Ball, S. Dwight, S. Chervitz, Y. Jia, G. Juvik, S. Weng, and D. Botstein. 1996. Saccharomyces Genome Database. http://genome-www.stanford.edu/Saccharomyces/ 1996.

Chu, S., J.M. Zengel, and L. Lindahl. 1997. A novel protein shared by RN ase MRP and RN ase P. RNA 3: 382-391.

Clayon, D. 1994. A nuclear function for RN ase M RP. Proc. N atl. Acad. Sci. 91: 4615-4617.

Darr, S.C., J.W. Brown, and N.R. Pace. 1992. The varieties of ribonuclease $P$. Trends Biochem. Sci. 17: 178-182.

Dichtl, B. and D. Tollervey. 199. POP3p is essential for the activity of RN ase MRP and RN ase $P$ ribonucleopoteins in vivo. EMBO J. 16: 417-429.

Drainas, D., S. Zimmerly, I. Willis, and D. Soll. 1989. Substrate structural requirements of Schizosaccharomyces pombe RN ase P. FEBS Lett. 251: 84-88.

Eder, P.S., A. Srinivasan, M.C. Fishman, and S. Altman. 1996. The RNA subunit of ribonuclease $P$ from the zebrafish, Danio rerio. J. Biol. Chem. 271: 21031-21036.

Eder, P.S., R. Kekuda, V. Stolc, and S. Altman. 1997. Characterization of two scleroderma autoimmune antigens that copurify with human ribonuclease P. Proc. Natl. Acad. Sci. 94: 1101-1106.

Eichler, D.C. and N . Craig. 1994. Processing of eukaryotic ribosomal RN A. Prog. Nucleic Acid Res. Mol. Biol. 49: 197-239.

Filipowicz, W. and T. Kiss. 1993. Structure and function of nucleolar snRN Ps. Mol. Biol. Reports 18: 149-156.

Forster, A.C. and S. Altman. 1990. Similar cage-shaped structure for the RNA components of all ribouclease $\mathrm{P}$ and ribonuclease MRP emzymes. Cell 62: 407-409.

Founier, M.J. and E.S. Maxwell. 1993. The nucleolar snRN As: Catching up with the spliceosomal snRNAs. Trends Biochem. Sci. 18: 131-135.

Girard, J.P., H. Lehtonen, M. Caizergues-Ferrer, F. Amalric, D. Tollervey, and B. Lapeyre. 1992. GAR1 is an essential small nucleolar RN P protein required for pre-rRNA processing in yeast. EMBO J. 11: 673-682.

Goffeau, A., B.G. Barrell, H. Bussey, R.W. Davis, B. Dujon, H. Feldmann, F. Gali ibert, J.D. Hoheisel, C. Jacq, M. Johnston, E.J. Louis, H.W. Mewes, Y. Murakami, P. Philippsen, H. Tettelin, and S.G. Oliver. 1996. Life with 6000 genes. Science 274: 563-567.

Gopalan, V., A.D. Baxevanis, D. Landsman, and S. Altman. 
1997. A nalysis of the functional role of conserved residues in the protein subunit of ribonuclease $P$ from Escherichia coli. J. Mol. Biol. 267: 818-829.

Guerrier-Takada, C., K. Gardiner, T. Marsh, N. Pace, and S. Altman. 1983. The RNA moiety of ribonuclease $P$ is the catalytic subunit of the enzyme. Cell 35: 849-857.

Guerrier-Takada, C., Y. Li, and S. Altman. 1995. Artificial regulation of gene expression in Escherichia coli by RN ase P. Proc. Natl. Acad. Sci. 92: 11115-11119.

Guthrie, C. and G.R. Fink. 1991. Guide to yeast genetics and molecular biology. Methods Enzymol. 194: 1-539.

Hartmann, R.K., J. Heinrich, J. Schlegl, and H. Schuster. 1995. Precursor of $\mathrm{C} 4$ antisense RN A of bacteriophages $\mathrm{P} 1$ and $\mathrm{P} 7$ in a substrate for RN ase P of Escherichia coli. Proc. Natl. Acad. Sci. 92: 5822-5826.

Haas, E.S., D.W Armbruster, B.M . Vucson, C.J. Daniels, and J.W. Brown. 1996. Comparative analysis of ribonuclease P RNA structure in Archaea. Nucleic Acids Res. 24: 1252-1259.

Henry, Y., H. Wood, J.P. M orrissey, E. Petfal ski, S. Kearsey, and D. Tollervey. 1994. The $5^{\prime}$ end of yeast 5.8S rRN A is generated by exonucleases from an upstream cleavage site. EMBO J. 13: 2452-2463.

Hughes, J.M. and M. Ares, Jr. 1992. Depletion of U3 small nucleolar RNA inhibits cleavage in the $5^{\prime}$ external transcribed spacer of yeast pre-ribosomal RNA and impairs formation of 18S ribosomal RNA. EMBO J. 10: 4231-4239.

Jansen, R., D. Tollervey, and E.C. Hurt. 1993. A U3 snoRN P protein with homology to splicing factor PRP4 and G betadomains is required for ribosomal RNA processing. EMBO J. 12: 2549-2558.

Johnston, M., S. Andrews, R. Brinkman, J. Cooper, H. Ding, J. Dover, Z. Du, A. Favello, L. Fulton, S. Gattung et al. 1994. Complete nucleotide sequence of Saccharomyces cerevisiae chromosome VIII. Science 265: 2077-2082.

Komine, Y., M. Kitabatake, T. Y okogawa, K. N ishikawa, and H. Inokuchi. 1994. A tRN A-like structure is present in 10Sa RN A, a small stable RNA from Escherichia coli. Proc. Natl. Acad. Sci. 91: 9223-9227.

Lee, B., A.G. Matera, D.C. Ward, and J. Craft. 1996. Association of RN ase mitochondrial RN A processing enzyme with ribonuclease $P$ in higher ordered structures in the nucleolus: $A$ possible coordinate role in ribosome biogenesis. Proc. Natl. Acad. Sci. 93: 11471-11476.

Lee, J.Y., C.E. Rohlman, L.A. Molony, and D.R. Engelke. 1991. Characterization of RPR1, an essential gene encoding the RNA component of Saccharomyces cerevisiae nuclear RN ase P. Mol. Cell. Biol. 11: 721-730.

Li, H.J., J. Zagorski, and M.J. Fournier. 1990. Depletion of U 14 small nuclear RNA (snR128) disrupts production of $18 \mathrm{~S}$ rRNA in Saccharomyces cerevisiae. Mol. Cell. Biol. 10: $1145-1152$.

Lindahl, L., R.H. Archer, and J.M. Zengel. 1992. A new rRN A processing mutant of Saccharomyces cerevisiae. Nucleic ACids Res. 20: 295-301.

Liu, F. and S. Altman. 1994. Differential evolution of substrates for an RNA enzyme in the presence and absence of its protein cofactor. Cell 77: 1093-1100.

Lygerou, Z., P. Mitchell, E. Petfalski, B. Seraphin, and D. Tollervey. 1994. The POP1 gene encodes protein component common to the RN ase MRP and RN ase P ribonucleoproteins. Genes \& Dev. 8: 1423-1433.

Lygerou, Z., C. Allmang, and B. Seraphin. 1996a. Accurate processing of a eukaryotic precursor ribosomal RNA by ribonuclease MRP in vitro. Science 272: 268-270.

Maxwell, E.S. and M.J. Fournier. 1995. The small nucleolar RNAs. Annu. Rev. Biochem. 64: 897-934.
Morrissey, J.P. and D. Tollervey. 1993. Yeast snR30 is a small nucleolar RN A required for $18 \mathrm{~S}$ rRN A synthesis. Mol. Cell. Biol. 13: 2469-2477.

- - 1995. Birth of the snoRN Ps: The evolution of RN ase MRP and the eukaryotic pre-rRNA-processing system. Trends Biochem. Sci. 20: 78-82.

Pace, N.R. and A.B. Burgin. 1990. Processing and evolution of therRN As. In The ribosome (ed. W.E. Hill), p. 418. American Society for Microbiology, Washington, D.C.

Sambrook, J., E.F Fritsch, and T. Maniatis. 1989. Molecular cloning: A laboratory manual. Cold Spring Harbor Laboratory Press, Cold Spring Harbor, NY.

Schmnitt, M.E. and D.A. Clayton. 1992. Yeast site-specific ribonucleoprotein endoribonuclese MRP contains an RNA component homologus to mammalian RNAse MRP RNA and essential for cell viability. Genes \& Dev. 6: 1975-1985.

_- - 1993. N uclear RN ase MRP is required for correct processing of pre-5.8S rRN A in Saccharomyces cerevisiae. Mol. Cell. Biol. 13: 7935-7941.

Schmitt, M.E., J.L. Bennett, D.J. Dairaghi, and D.A Clayton. 1993. Secondary structure of RN ase MRP RN A as predicted by phylogenetic comparison. FASEB J. 7: 208-213.

Shuai, K. and J.R. Warner. 1991. A temperature sensitive mutant of Saccharomyces cerevisiae defective in pre-rRN A processing. Nucleic Acid Res. 19: 5059-5064.

Stohl, L.L. and D.A. Clayton. 1992. Saccharomyces cerevisiae contains an RN ase MRP that cleaves at a conserved mitochondrial RNA sequence implicated in replication priming. Mol. Cell. Biol. 12: 2561-2569.

TerBush, D.R. and P. N ovick. 1996. The exocyst is a multiprotein complex required for exocytosis in Saccharomyces cerevisiae. EMBO J. 23: 6483-6494.

Tollervey, D. 1987. A yeast small nuclear RNA is required for normal processing of pre-ribosomal RNA. EMBO J. 6: 41694175.

-_- 1996. Small nucleolar RNAs guide ribosomal RNA methylation. Science 273: 1056-1057.

Tollervey, D., H. Lehtonen, M. Carmo-Fonseca, and E.C. Hurt. 1991. The small nucleolar RN P protein NOP1 (fibrillarin) is required for pre-rRN A processing in yeast. EMBO J. 10: 573583.

Tranguch, A.J. and D.R. Engelke. 1993. Comparative structural analysis of nuclear RN ase P RN As from yeast. J. Biol. Chem. 268: 14045-14055.

Van Nues, R.W., J.M.J. Rientjes, C.A.F.M. Van der Sande, S.F. Zerp, C. Sluiter, J. Venema, R.J. Planta, and H.A. Raue. 1994. Separate structural elements within internal transcribed spacer 1 of Saccharomyces cerevisiae precursor ribosomal RNA direct the formation of 175 and $26 \mathrm{~S}$ rRNA. Nucleic Acids Res. 22: 912-929.

Venema, J. and D. Tollervey. 1995. Processing of pre-ribosomal RNA in Saccharomyces cerevisiae. Yeast 11: 1629-1650.

- - . 1996. RRP5 is required for formation of both $18 \mathrm{~S}$ and 5.85 rRN A in yeast. EMBO J. 15: 5701-5714.

Yuan, Y. and S. Altman. 1995. Substrate recognition by human RN ase P: Identification of small, model substrates for the enzyme. EMBO J. 14: 159-168. 


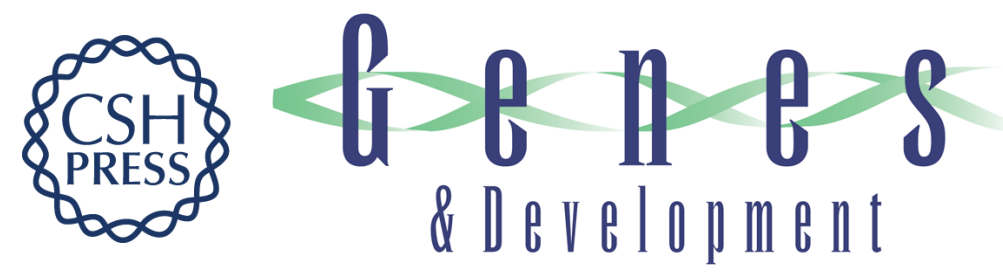

\section{$R p p 1$, an essential protein subunit of nuclear $R$ Nase $P$ required for processing of precursor tRNA and 35S precursor rRNA in Saccharomyces cerevisiae}

Viktor Stolc and Sidney Altman

Genes Dev. 1997, 11:

Access the most recent version at doi:10.1101/gad.11.21.2926

References This article cites 57 articles, 23 of which can be accessed free at: http://genesdev.cshlp.org/content/11/21/2926.full.html\#ref-list-1

License

Email Alerting

Receive free email alerts when new articles cite this article - sign up in the box at the top

Service right corner of the article or click here.

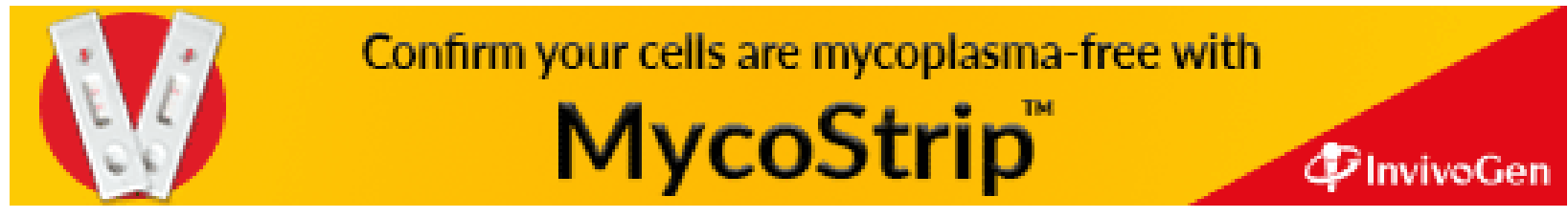

